\title{
Bench-scale study of acid mine drainage treatment using local neutralisation agents
}

Norinsafrina Mustaffa Kamal* and Shamsul Kamal Sulaiman

Mineral Research Centre, Jalan Sultan Azlan Shah, 31400 Ipoh, Perak

*Corresponding Author: norin@jmg.gov.my (Norinsafrina Mustaffa Kamal)

\section{Article history :}

Received 20 March 2014

Revised 30 April 2014

Accepted 29 June 2014

Available online 7 July 2014

\section{GRAPHICAL ABSTRACT}

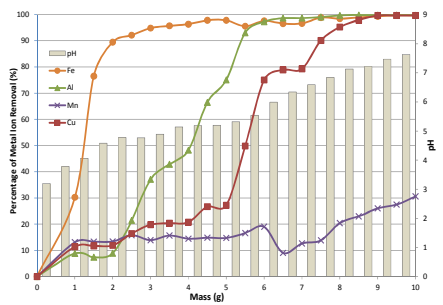

\section{ABSTRACT}

Bench-scale experiments were conducted to evaluate the treatment performance of alternative alkaline media; serpentinite and concrete waste compared to conventional treatment with common neutralisation agents namely hydrated lime and limestone in terms of reducing acidity and metals concentrations in acid mine drainage (AMD) samples taken from effluent of an abandoned copper mine located in Mamut, Sabah. Parameters tested in these experiments include particle size and mass of the materials. The tests were performed using a jar tester with the particle size varies at $45 \mu \mathrm{m}, 75 \mu \mathrm{m}$ and $150 \mu \mathrm{m}$ and the mass was put to $1-10$ grams with incremental dosing of 0.5 grams for every 20 minutes. Results of the study showed that hydrated lime, limestone and concrete waste with different sizes and mass were capable in achieving $\mathrm{pH}$ targets required for neutralisation of the AMD. Overall, metal concentrations of $\mathrm{Fe}, \mathrm{Al}$ and $\mathrm{Cu}$ followed a certain reduction trends whilst Mn has shown a poor reduction.

Keywords: Neutralisation Agent, Limestone, Hydrated Lime, Serpentinite, Concrete Waste, Acid Mine Drainage

(c) 2014 Penerbit UTM Press. All rights reserved http://dx.doi.org/10.11113/mjfas.v10n3.272

\section{INTRODUCTION}

Acid mine drainage (AMD) is an unavoidable wastewater of the mining industry characterised by its low $\mathrm{pH}$-value and high concentrations of sulphate and metals [1]. It is a serious environmental concern as a result of sulphide minerals weathering activity, such as pyrite $\left(\mathrm{FeS}_{2}\right)$ due to exposure of fresh iron and sulphide surfaces to oxygen. High level of dissolved iron which exists in reduced form $\left(\mathrm{Fe}^{2+}\right)$ or in oxidised form $\left(\mathrm{Fe}^{3+}\right)$ is often associated with AMD. Sulphide minerals oxidise and discharge dissolved ferrous ion and acidity into water which consequently releases other metal ions such as $\mathrm{Fe}^{3+}, \mathrm{Al}^{2+}$, $\mathrm{Mn}^{+}$and $\mathrm{Cu}^{2+}$ which are not biodegradable. If left unattended, AMD can pollute surface and ground water, harming the health of aquatic flora and fauna [2] and causing heavy metal accumulation in living organisms, causing various diseases and disorders [3].

Several treatment methods have been adopted in treating acid mine drainage such as precipitation, oxidation and hydrolysis, neutralisation, ion exchange, titration, adsorption and reverse osmosis [1]. Most of AMD treatment systems use hydrated lime and limestone as an acidity neutralising agent in order to increase $\mathrm{pH}$ and enhance metal precipitation. However, the use of hydrated lime and limestone are unsustainable due to high economic and environmental costs [4]. Thus, economically feasible, based on local and readily available neutralising agent need to be sought. Serpentinite is a good source due to its alkaline nature [5] plus it is readily available at the mine site. In addition, waste product such as concrete waste has potential to be recycled as a neutralisation agent.

The current work is focused on evaluating treatment performance of alternative alkaline media; serpentinite and concrete waste compared to conventional treatment with common neutralisation agents namely hydrated lime and limestone in terms of raising $\mathrm{pH}$ level and removing metal ions concentrations from AMD.

\section{MATERIALS AND METHOD}

\subsection{Neutralisation agents}

Four alkaline materials were used in this study which are common neutralisation agents; hydrated lime and limestone against alternative alkaline media; serpentinite and concrete waste. Industrial grade hydrated lime with $90 \% \mathrm{Ca}(\mathrm{OH})_{2}$ was used for the experiments. Limestones were obtained from Sukau Quarry in Sandakan, Sabah while serpentinite stones were collected from the vicinity of the ex-copper mine in Mamut, Sabah. Blocks of concrete wastes were obtained from a common construction site in Kota Kinabalu, Sabah. All materials were ground and sieved to sizes of $-150+125 \mu \mathrm{m},-75+63 \mu \mathrm{m}$ and $-45 \mu \mathrm{m}$. 


\subsection{Mine water}

Raw mine water samples were collected from the main pit lake of Ex-Mamut copper mine. The major contaminants of this mine effluent are acidity $(\mathrm{pH}=3.0 \pm 0.1)$, electrical conductivity $(\mathrm{EC}=1944.71$ $\mu \mathrm{S} / \mathrm{cm} \pm 0.01)$, iron $(\mathrm{Fe}=4.42 \mathrm{mg} / \mathrm{l})$, aluminium $(\mathrm{Al}=31.39$ $\mathrm{mg} / \mathrm{l})$, manganese $(\mathrm{Mn}=9.18 \mathrm{mg} / \mathrm{l})$ and copper $(\mathrm{Cu}=4.35$ $\mathrm{mg} / \mathrm{l})$. Values for these contaminants were averaged from 12 samples taken at the time of each batch experiment. Acidic water and high concentration of metal ions implies that the effluent have to be treated before discharge into the receiving environments.

\subsection{Experimental procedures}

This study consists of 12 batch experiments which involved 4 types of neutralisation agents with 3 different sizes. Each batch test was performed using a standard jar tester. 10 litres of the mine water sample was filled into the jar and mixed steadily at 200 to $250 \mathrm{rpm}$. $25 \mathrm{~mL}$ of raw water sample was taken from the jar prior to the experiment for initial parameters measurements. Neutralisation agent with mass of 1 to 10 grams were then added with incremental dosing of 0.5 grams for every 20 minutes. 25 $\mathrm{ml}$ of treated water was sampled prior to every addition of the neutralisation agent after which it was analysed for $\mathrm{pH}$ and metal ions (Fe, $\mathrm{Al}, \mathrm{Mn}$ and $\mathrm{Cu}$ ) concentrations.

\section{$2.4 \quad$ Analytical methods}

pH was measured using Thermo Scientific Orion 4Star multiparameter meter. The metal ions concentrations of the samples were analysed by Perkin Elmer Optima DV 5300 ICP-OES. Samples to be analysed for metals ions were filtered through a $0.45 \mathrm{~mm}$ membrane filter after which they were acidified using concentrated nitric acid.

\section{RESULTS AND DISCUSSION}

\subsection{Changes in $\mathbf{p H}$}

The initial $\mathrm{pH}$ for the raw mine water samples was 3.0. Overall, $\mathrm{pH}$ of the mine water increased from $\mathrm{pH} 3$ to $\mathrm{pH} 13$ when treated with hydrated lime (Figure 1). It only required small dosing of 2.0-2.5 grams of hydrated lime for all particles sizes to reach neutral $\mathrm{pH}$. Hydrated lime with size $-45 \mu \mathrm{m}$ reached $\mathrm{pH} 7.0$ the quickest; at dosage of 2.0 grams because larger surface area of the smaller particle size has more potential reaction sites [6]. All sizes of the neutralisation agent started with sharp increment and plateau at $\mathrm{pH} 9-10$ at dosing of 3.0 to 5.5 grams. Then, $\mathrm{pH}$ started to rise again at dosing of 6.0 grams in gradual manners till the end of the experiments. Particle size of $150+125 \mu \mathrm{m}$ gave the best results among the three neutralisation agent's sizes; most probably because the larger particles dissolve and break into smaller ones promoting more sites of reactions [7].

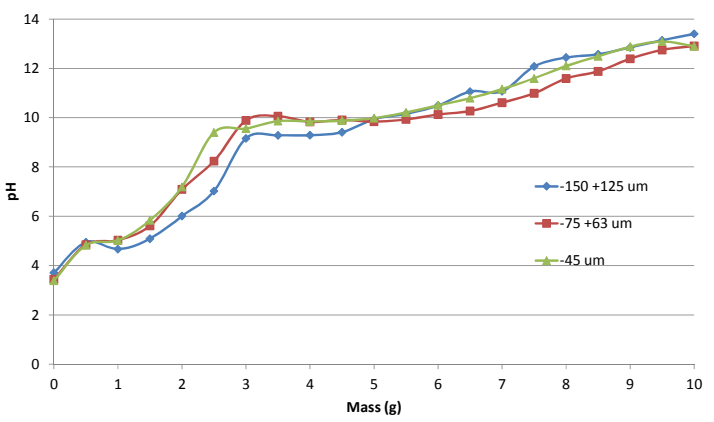

Fig. $1 \mathrm{pH}$ changes of the mine water treated with hydrated lime of different sizes

Figure 2 shows that limestone recorded good performances for all particles sizes of $-150+125 \mu \mathrm{m}$, $75+63 \mu \mathrm{m}$ and $-45 \mu \mathrm{m}$ in terms of raising $\mathrm{pH}$ of the mine water to $\mathrm{pH}$ 7.0. $\mathrm{pH}$ started to enter neutral region at the dosage higher than 5.5 grams for limestone's sizes of $150+125 \mu \mathrm{m}$ and $-75+63 \mu \mathrm{m}$. Limestone with size $-45 \mu \mathrm{m}$ reached pH 7.0 much faster; at dosage of 4.5 grams because smaller particle size has larger surface area for higher rate of reaction with the acidic water [6]. In general, $\mathrm{pH}$ increments by the treatments with limestone for all particles sizes were in a positive trending throughout the tests.

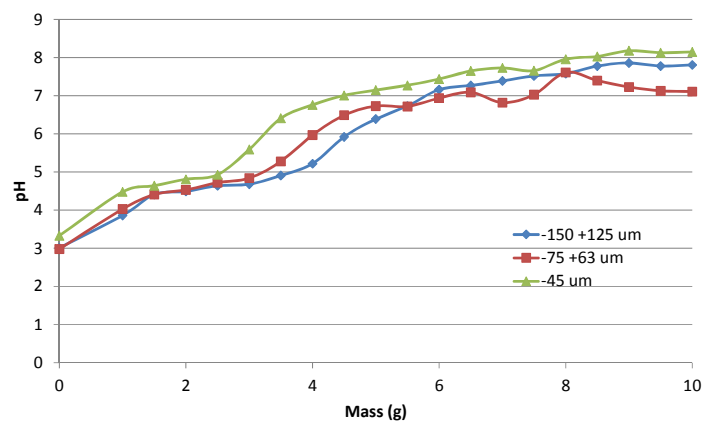

Fig. $2 \mathrm{pH}$ changes of the mine water treated with limestone of different sizes

Serpentinite had a poor performance as shown in Figure 3. No significant $\mathrm{pH}$ changes of the mine water were observed during the experiments. Final $\mathrm{pH}$ recorded in all experiments were only $~ 3.5$ compared to the initial $\mathrm{pH}$ of 3.0. Fluctuation trends plotted in the graphs are merely straight lines indicate no substantial events. This is probably due to pyrite $\left(\mathrm{FeS}_{2}\right)$ dissolute from the serpentinite [8] thus affecting the $\mathrm{pH}$ condition [9].

The mine water $\mathrm{pH}$ showed gradual increments until final dosage by the treatment with concrete waste of all sizes (Figure 4). Concrete waste with particle size $-45 \mu \mathrm{m}$ gave the best outcome given that it has larger surface area available for reaction to occur [6]. However, it only reached $\mathrm{pH} 7.0$ at a high dosage of 8.5 grams whilst other sizes did not reach the neutral region at all. Small ratio of alkaline material in the concrete waste compares to the hydrated lime and the limestone probably is the contributing factor for the temperate $\mathrm{pH}$ changes. 


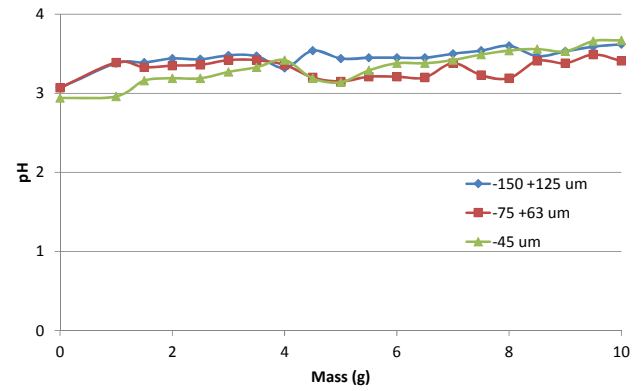

Fig. $3 \mathrm{pH}$ changes of the mine water treated with serpentinite of different sizes

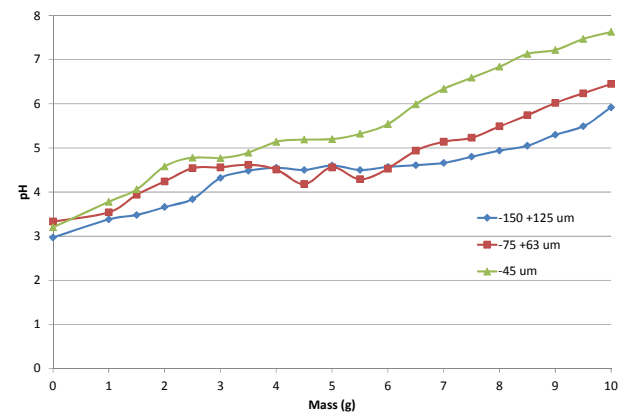

Fig. $4 \mathrm{pH}$ changes of the mine water treated with concrete waste of different sizes

\subsection{Removal of metal ions}

\section{Hydrated lime, $-150+125 \mu m$}

Hydrated lime with size $-150+125 \mu \mathrm{m}$ is the best size for metal ions removals treatment compared with other sizes. According to the graph in Figure 5, Fe is the quickest to be removed starting at $\mathrm{pH}>3.0$ due to the fact that $\mathrm{Fe}$ starts to precipitate at $\mathrm{pH}>3.5$ and forms iron (III) hydroxides [10]. On the other hand, Mn was the slowest to be removed. Mn percentage removal increased to $97 \%$ at $\mathrm{pH} 9.2$ since it only precipitate out at $\mathrm{pH}>8.5$ [11]. Most metal ions attain their minimum solubility in alkaline region [12] affecting almost all metal ions had been removed completely starting at 4.5 grams at $\mathrm{pH} 9.4$ till the end of the test.

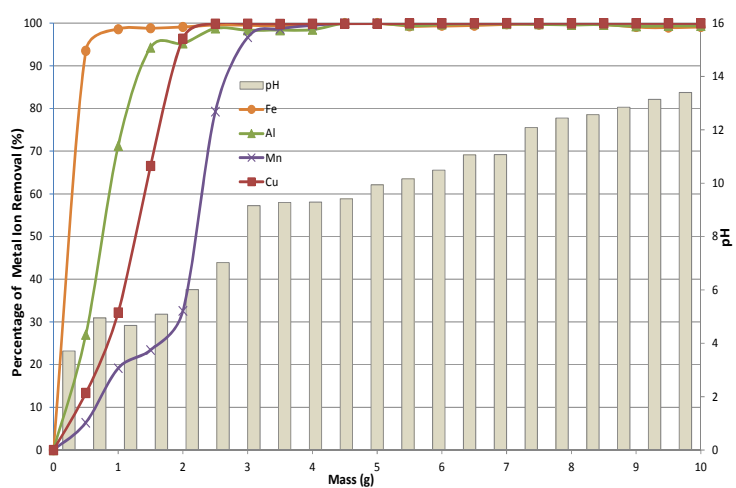

Fig. 5 Percentages of metal ions removals and $\mathrm{pH}$ changes by treatment with -150+125 $\mu$ m hydrated lime

\section{Limestone, $-45 \mu m$}

Figure 6 presents percentage of metal ions removals by limestone with size $-45 \mu \mathrm{m}$ which produced the greatest results for metal ions removals with other sizes. The graph shows removals of the metal ions is in the order of $\mathrm{Fe}>\mathrm{Al}$ $>\mathrm{Cu}>\mathrm{Mn}$. All metal ions except for Mn were removed remarkably from the mine water at dosage of 5.0 grams and above. Percentages of metal ions that had been removed at dosage of 5.0 grams at $\mathrm{pH} 7.2$ are $\mathrm{Fe}=99.0 \%, \mathrm{Al}=99.8 \%$, $\mathrm{Cu}=98.3 \%, \mathrm{Mn}=11.4 \%$. All metal ions except for Mn was probably being removed by precipitation as Fe starts precipitates at $\mathrm{pH}>3.5$, Al precipitates at $\mathrm{pH}>5$ and $\mathrm{Cu}$ precipitates at $\mathrm{pH}>4$ [13].Clearly, $\mathrm{pH}$ is an important factor in the removal of metal ions. However, poor removal of $\mathrm{Mn}$ had been observed with only $27 \%$ of maximum removal throughout the whole study. The highest $\mathrm{pH}$ recorded was only at $\mathrm{pH} \sim 8$ which do not assist removal of Mn since it only precipitate at $\mathrm{pH}>8.5$ [11].

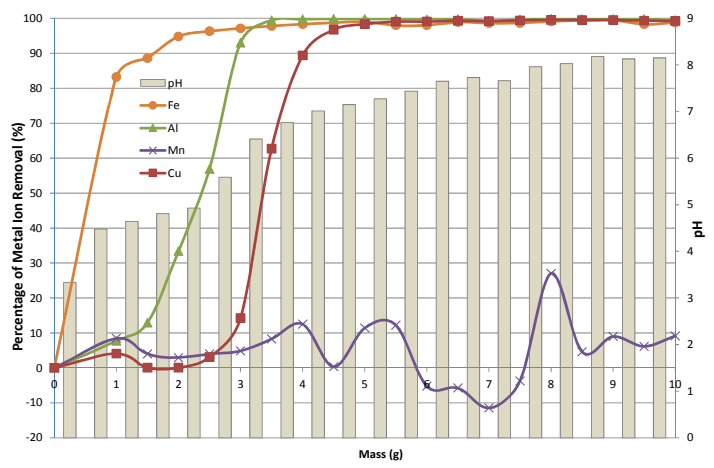

Fig. 6 Percentages of metal ions removals and $\mathrm{pH}$ changes by treatment with $-45 \mu \mathrm{m}$ limestone

\section{Serpentinite, $-75+63 \mu \mathrm{m}$}

In general, serpentinite did not perform well in terms of metal ions removals. The utmost performance among the three sizes was size $-75+63 \mu \mathrm{m}$. By referring to the graph in Figure 7, the overall performance was very poor with less than $35 \%$ of metal ions removals. The $\mathrm{pH}$ was below 3.5 throughout the experiment suggests that most probably pyrite $\left(\mathrm{FeS}_{2}\right)$ from the serpentinite dissolute and influencing the $\mathrm{pH}$ condition to be kept in acidic region [9]. Removals of all metal ions followed a certain fluctuating trend within the $\mathrm{pH}$ condition. Further study is needed for more explanation.

\section{Concrete waste, $-45 \mu \mathrm{m}$}

Concrete waste with size $-45 \mu \mathrm{m}$ gave the best results for metal ions removals compared with other sizes that were tested. Generally, results of metal ions removals by the concrete waste, $-45 \mu \mathrm{m}$ (Figure 8 ) were similar to results produced by the limestone, $-45 \mu \mathrm{m}$ which in the order of $\mathrm{Fe}>\mathrm{Al}>\mathrm{Cu}>\mathrm{Mn}$ but substantial removals of all metal ions except for Mn only occurred at dosage of more than 8.0 grams which is close to the completion of the test. 
Rate of metal removal was affected by gradual $\mathrm{pH}$ increment thus influencing pH-metal hydroxides solubility relations [13]. Again, poor removal of Mn was detected with maximum removal of $20 \%$ during the experiment as $\mathrm{pH}$ was $<8.5$.

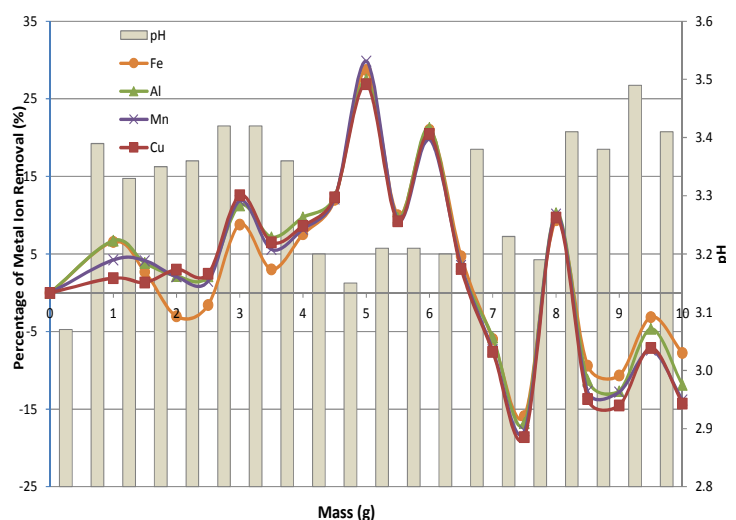

Fig. 7 Percentages of metal ions removals and $\mathrm{pH}$ changes by treatment with $-75+63 \mu \mathrm{m}$ serpentinite

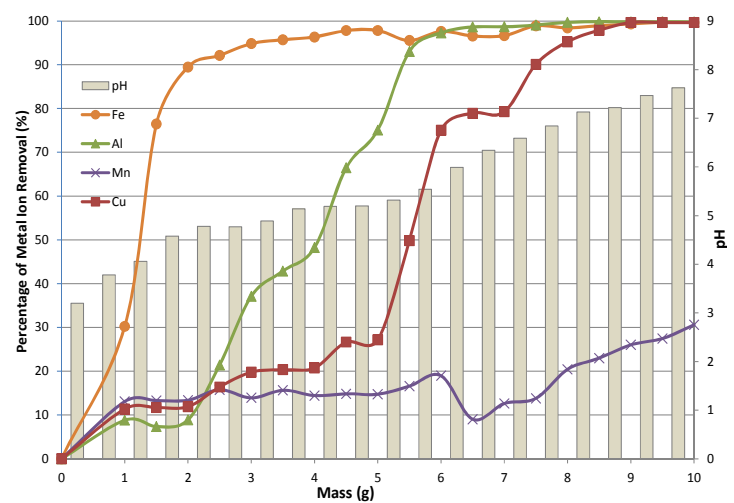

Fig. 8 Percentages of metal ions removals and $\mathrm{pH}$ changes by treatment with $-45 \mu \mathrm{m}$ concrete waste

\section{CONCLUSION}

Serpentinite and concrete waste have lower performance in raising $\mathrm{pH}$ level and reducing metals concentrations in AMD compared to hydrated lime and limestone. Hydrated lime with size of $-150+125 \mu \mathrm{m}$ followed gave the best results followed by limestone with size of $-45 \mu \mathrm{m}$ and concrete waste with size of $-45 \mu \mathrm{m}$. Serpentinite is not suitable to be utilise as neutralising agent. This study has shown that only small dosages of the hydrated lime and the limestone are required to neutralise the mine water but large dosage is needed for the concrete waste to work. Again, cost-effective and sustainable resources are yet the other factors which determine the worthiness of the neutralising agents.

\section{ACKNOWLEDGEMENT}

The authors would like to thank Dato' Hj. Zulkifly bin Abu Bakar, the Director of Mineral Research Centre and the staff of Mining and Quarrying Unit, Jabatan Mineral dan Geosains (JMG) Sabah and Mine Reclamation Corporation (MIRECO), Korea for their supports and helps during this study.

\section{REFERENCES}

[1] D. Mohan and S. Chander, J. Hazardous Materials, B137 (2006), 1545.

[2] C.A Rios, C.D. Williams, and C.L. Roberts, J. Hazardous Materials, 156 (2008) 23.

[3] Myroslav, Sprynskyy, Boguslaw, Buszewski, Artur, P. Terzyk, Jacek and Namiesnik, J. Colloid Interface Sci., 304 (2006) 21.

[4] R. P. Lopez, J. Castillo, D. Quispe, and J. M. Nieto, 2010, J. Hazardous Materials, 177 (2010) 762.

[5] L.R. Bernier, Env. Geology, 47(5) (2005) 670-684.

[6] C.J. Lewis and R.S. Boynton, Acid Neutralisation with Lime for Environmental Control and Manufacturing Processes, Bulletin no.216, Natural Lime Association, Virginia, 1995, 8.

[7] B. Sun, Q. Zhou, X. Chen, T. Xu, and S. Hui, J. Hazardous Materials, 179 (2010) 400.

[8] K. Saibeh, M.H. Abdullah, B. Musta, K.Bisin and E. Saleh, Geological Mapping, Geochemical, Groundwater Quality and Limnology Studies of Ex-Copper Mine Mamut, Ranau, Sabah, Consultancy Report, UMS-Link Holdings Sdn. Bhd., Kota Kinabalu, Sabah, (2010).

[9] M. Descostes, P. Vitorge, and C. Beaucaire, Geochimica et Cosmochimica Acta, 68(22) (2004) 4559.

[10] M. Balintova and A. Petrilakova, Chem. Eng. Transactions, 25 (2011) 345.

[11] A. M. Silva, E.C. Cunha, F.D.R. Silva, V.A. Leao, J. Cleaner Production, 29-30 (2012) 11.

[12] N.R. Hendricks, The application of high capasity ion exchange adsorbent material, synthesised from fly ash and acid mine drainage, for the removal of heavy metals from secondary codisposed process waters. Master's thesis, University of Western Cape, South Africa, (2005).

[13] P. M. Armenante, Precipitation of Heavy Metals from Wastewaters, Slide Presentation, NJIT, (1997). 